\title{
Pasture species effects on carcass and meat quality
}

\author{
T.J. FRASER ${ }^{1}$, S.M. SCOTT ${ }^{2}$ and J.S. ROWARTH ${ }^{1,3}$ \\ ${ }^{1}$ AgResearch, PO Box 60, Lincoln, Canterbury \\ ${ }^{2}$ Meat Industry Research Institute of New Zealand (Inc.), PO Box 617, Hamilton \\ ${ }^{3}$ Plant Science Department, PO Box 84, Lincoln University, Canterbury
}

\begin{abstract}
Increasing concerns about food quality and animal fat in the human diet have promoted research into the effects of different forage species on carcass quality and fat content. This trial investigated the effect on carcass composition and the intensity of sheep meat flavour and odour of five different pure pasture species: Grasslands Lancelot plantain (Plantago lanceolata), Grasslands Puna chicory (Cichorium intybus), Grasslands Huia white clover (Trifolium repens), Grasslands Nui high-endophyte perennial ryegrass (Lolium perenne) and Grasslands Goldie lotus (Lotus corniculatus). Although pasture species did affect meat quality and fat content, there appeared to be an inverse relationship with carcass weight: larger lambs had more fat, which was related to difference in body size and relative maturity rather that pasture species. Pasture species also influenced muscle ultimate $\mathrm{pH}$, sheep meat odour, foreign odours, and flavours, but did not affect sheep meat flavour.
\end{abstract}

Keywords: Cichorium intybus, meat flavour, Lolium perenne, Lotus corniculatus, meat odour, Plantago lanceolata, Trifolium repens

\section{Introduction}

Increasing concerns about food quality and animal fat in the human diet have promoted investigations into the effects of different forage species on carcass quality and fat content. Lambs grazing Lotus pedunculatus, which contains tannins, are reported to have lower levels of fatness at the same carcass weight than their counterparts grazing white clover (Purchas \& Keogh 1984). Tannins in sulla (Hedysarum coronarium) have also been shown to reduce carcass fatness (Terrill et al. 1992a). Chicory (Cichorium intybus L.; Terrill et al. 1992b) and plantain (Plantago lanceolata L.; Dorfler \& Roselt 1989) are reported to contain tannins, thus they, too, might affect carcass composition.

Flavour is also of concern in meat quality. Over the past 30 years many studies have been conducted to determine if diet influences the flavour of sheep meat. Several studies have shown that meat from lambs grazed on white clover pastures has a more intense flavour than that from lambs grazed on ryegrass (Cramer et al. 1967; Czochanska et al. 1970; Shorland et al. 1970). In contrast, a large study by Purchas et al. (1986) found that pasture type did not significantly affect the flavour of the lamb, although there was a trend for lambs fed on lotus or white clover to have a stronger flavour than those grazed on lucerne or perennial ryegrass.

The present study examined the effect of pasture species on animal productivity (see Fraser \& Rowarth 1996), carcass quality, and sheep meat odour and flavour.

\section{Materials and methods}

Pure stands of Grasslands Lancelot plantain (Plantago lanceolata L.), Grasslands Puna chicory (Cichorium intybus L.), Grasslands Huia white clover (Trifolium repens L.), Grasslands Nui high-endophyte perennial ryegrass (Lolium perenne L.) and Grasslands Goldie lotus (Lotus corniculatus L.) were established in spring 1992 at AgResearch Lincoln. Grazing periods were 83 days in year 1 and 120 days in years 2 and 3 . Full details of trial protocol were given by Fraser \& Rowarth (1996).

Carcass weight, dressing-out \%, ultrasound GR, actual GR (measured over the 12th rib, $11 \mathrm{~cm}$ from the midline of the spine, with a sharpened stainless steel ruler), muscle ultimate $\mathrm{pH}$., and, for year 1 of trial, carcass composition including muscle:bone ratio and fat:bone ratio were measured on half carcasses from 20 lambs per treatment.

In year 3, one leg was removed from each carcass after development of rigour, frozen at $-35^{\circ} \mathrm{C}$, and prepared for ultimate $\mathrm{pH}$ determination and sensory evaluation. Ultimate $\mathrm{pH}$ was determined from shavings from the semi-membranous muscle of the frozen legs, placed into $10 \mathrm{ml}$ distilled water and homogenised. An Orion Ross spear electrode (8130), attached to an Orion SA250 meter, was used to measure the $\mathrm{pH}$ of the homogenate. Two lamb legs in the $\mathrm{pH}$ range of 5.565.63 (mean $\mathrm{pH}$ 5.6; low $\mathrm{pH}$ samples) and two lamb legs in the $\mathrm{pH}$ range of 5.74-6.19 (mean $\mathrm{pH} 5.9$; high $\mathrm{pH}$ samples) were selected from each pasture type to eliminate the influence of meat $\mathrm{pH}$ on sensory traits (Young et al. 1993)

Meat was separated into fat and lean, and then recombined in the ratio 3:17 before being minced twice 
through a Bauknecht mincer with a $3 \mathrm{~mm}$ plate. Samples were frozen at $-35^{\circ} \mathrm{C}$ and thawed before sensory evaluation. Thirty minutes before tasting, each sample was placed into a separate stainless steel pot, covered with a lid to prevent odour transfer, and cooked in a boiling water bath until just brown. At this stage $2 \%$ (w/ w) caseinate and $1 \%(\mathrm{w} / \mathrm{w})$ starch were stirred into each mince sample to bind the fat and water, respectively. The sample was then cooked for another 5 minutes to allow the mince to thicken slightly (Cummings 1989). Each sample was served into $30 \mathrm{ml}$ polycarbonate portion cups which were placed in a Bain-marie and held until served to panellists (within 30 minutes).

For formal evaluation, trained panellists were randomly served five samples per session. Over the course of two sessions held on the same day, each panellist tasted one high and one low $\mathrm{pH}$ sample from each pasture type. Samples were scored for sheep meat odour and flavour and foreign odour and flavour. Each attribute was scored on a 10-point category scale where $0=$ absent and $9=$ intense.

Data were analysed using Genstat.

\section{Results and discussion}

Ultrasound GR (Table 1) and actual GR (Table 2) measurements were higher for white clover, lotus and chicory than for plantain and ryegrass. This was associated with greater carcass weight for white clover, lotus and chicory than for plantain and ryegrass (Fraser $\&$ Rowarth 1996). Dressing-out percentage varied with year but was always lowest for ryegrass. Carcass analysis (Table 3) showed that white clover-fed lambs had the greatest muscle:bone, but also had the greatest fat:bone. Ryegrass-fed lambs had the smallest fat:bone, but also had the smallest muscle:bone. The relationship between the two ratios was positive, indicating that increased muscle is associated with increased fat. This was supported by the results from all three years of the trial comparing GR and carcass weights $\left(\mathrm{R}^{2}=0.80\right)$.

Pasture species affected liver and kidney weights (Table 3). Adjustment for carcass weight removed some differences, but adjusted liver weights in white clover were significantly $(\mathrm{P}<0.05)$ higher than for other species.
This is consistent with results from Koong et al. (1983), who showed that fast-growing animals tend to have larger organs than slow-growing animals. Adjusted kidney weights were greatest in plantain, followed by white clover, chicory and ryegrass; all species were significantly different from each other $(\mathrm{P}<0.05)$. The heavy kidney weight in plantain-grazed lambs may have been due to the presence of active diuretics in the plantain (Deaker et al. 1994).

Lambs grazing white clover or lotus had significantly lower mean $\mathrm{pH}$ than those fed on plantain or ryegrass (Table 4); the $\mathrm{pH}$ of lambs grazing chicory was intermediate between those of these two groups. Lambs fed on white clover had a significantly stronger sheep meat odour than lambs fed on ryegrass or plantain, but pasture type did not influence the intensity of the sheep meat flavour (Table 5). Lambs fed on white clover or lotus also had a significantly higher foreign odour and foreign flavours than lambs fed on ryegrass, plantain or chicory. As the possible effect of $\mathrm{pH}$ on odour and flavour had been taken into account in the tasting trial design, it can be concluded that although pasture type significantly affected the ultimate $\mathrm{pH}$ of lambs, pasture type had no significant effect on sheep meat flavour intensity. This result supports work by Purchas et al. (1986) and Suzuki (1985).

\section{Conclusions}

Although pasture species affected meat quality and fat content, there appeared to be an inverse relationship with carcass weight: larger lambs had more fat, which was related to differences in body size and relative maturity rather than pasture species (Deaker et al. 1994).

Table 1 Effect of pasture species on ultrasonically assessed GR (mm).

\begin{tabular}{|c|c|c|c|c|c|}
\hline Year & Chicory & Plantain & White clover & Lotus & Ryegrass \\
\hline One & $12.2 \pm 0.41$ & $10.6 \pm 0.4$ & $12.5 \pm 0.4$ & $\mathrm{n} / \mathrm{a}$ & $9.6 \pm 0.4$ \\
\hline Two & $12.6 \pm 0.7$ & $8.0 \pm 0.5$ & $15.7 \pm 0.5$ & $12.1 \pm 0.4$ & $7.1 \pm 0.3$ \\
\hline Three & $18.6 \pm 0.6$ & $12.3 \pm 0.5$ & $20.4 \pm 0.9$ & $19.8 \pm 0.5$ & $14.1 \pm 0.6$ \\
\hline
\end{tabular}

Table 2 Effect of pasture species on hot carcass weight $(\mathrm{kg})$ and $\mathrm{GR}(\mathrm{mm})$.

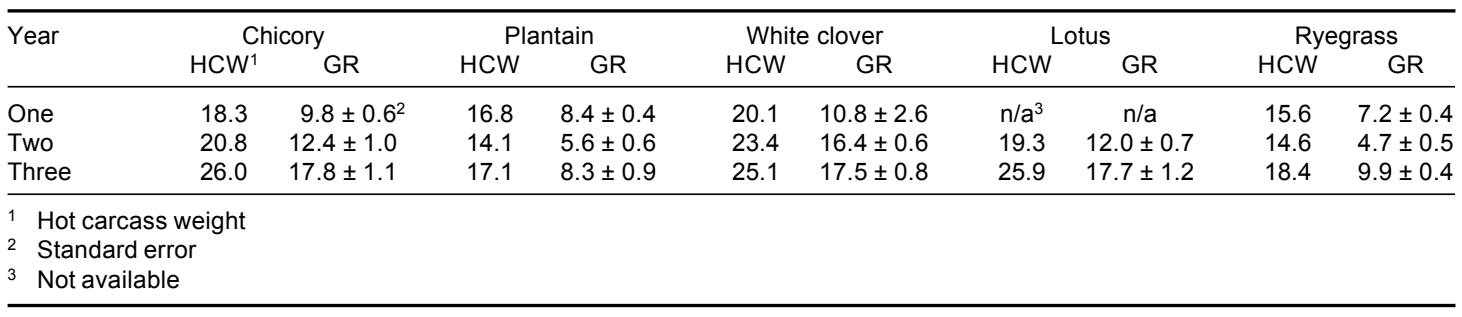


Table 3 Effect of pasture species on carcass weights, dressing out $\%$, muscle:bone and fat:bone ratios, kidney and liver weights in year one. All values adjusted to constant carcass weight by covariance.

\begin{tabular}{lcccc}
\hline & Chicory & Plantain & $\begin{array}{c}\text { White } \\
\text { clover }\end{array}$ & Ryegrass \\
\hline Carcass weight $(\mathrm{kg})$ & 18.3 & 16.8 & 20.1 & 15.6 \\
Dressing out \% & 47.9 & 47.9 & 48.3 & 45.2 \\
Muscle:bone & 3.49 & 3.47 & 3.51 & 3.43 \\
Fat:bone & 0.94 & 0.87 & 1.06 & 0.81 \\
Liver (g) & $648.9 \mathrm{~b}$ & $579.8 \mathrm{a}$ & $749.6 \mathrm{c}$ & $545.4 \mathrm{a}$ \\
Kidney (g) & $121.0 \mathrm{~b}$ & $142.5 \mathrm{c}$ & $135.1 \mathrm{c}$ & $101.5 \mathrm{a}$ \\
$\begin{array}{l}\text { Adjusted liver } \\
\quad \text { g/kg HCW) }\end{array}$ & $35.6 \mathrm{a}$ & $33.9 \mathrm{a}$ & $38.4 \mathrm{~b}$ & $34.5 \mathrm{a}$ \\
Adjusted kidney & & & & \\
$\quad$ (g/kg HCW) & $6.74 \mathrm{~b}$ & $8.17 \mathrm{~d}$ & $7.32 \mathrm{c}$ & $6.16 \mathrm{a}$ \\
\hline
\end{tabular}

Means within a row that do not share the same letter are significantly different at the $5 \%$ level.

Table 4 Effect of pasture species on mean, maximum and minimum ultimate $\mathrm{pH}$ values of meat in year 3 .

\begin{tabular}{lccccc}
\hline & Chicory & Plantain & $\begin{array}{l}\text { White } \\
\text { clover }\end{array}$ & Lotus & Ryegrass \\
\hline $\mathrm{n}$ & 15 & 14 & 13 & 16 & 17 \\
mean & $5.75 \mathrm{ab}$ & $5.89 \mathrm{bc}$ & $5.66 \mathrm{a}$ & $5.72 \mathrm{a}$ & $5.97 \mathrm{c}$ \\
max & 6.14 & 6.4 & 5.83 & 6.19 & 6.52 \\
min & 5.40 & 5.60 & 5.50 & 5.50 & 5.61 \\
\hline
\end{tabular}

Means within a row that do not share the same letter are significantly different at the $5 \%$ level.

Table 5 Effect of pasture species on sheep meat odour, sheep meat flavour, foreign odour and foreign flavour. Higher values indicate a greater intensity; tests were done on 2 high- $\mathrm{pH}$ and 2 low-pH legs for each treatment.

\begin{tabular}{lccccc}
\hline & Chicory & Plantain & $\begin{array}{l}\text { White } \\
\text { clover }\end{array}$ & Lotus & Ryegrass \\
\hline Sheep meat odour & $3.9 \mathrm{abc}$ & $3.5 \mathrm{c}$ & $4.7 \mathrm{a}$ & $4.4 \mathrm{ab}$ & $3.7 \mathrm{bc}$ \\
Sheep meat flavour & $5.1 \mathrm{a}$ & $5.2 \mathrm{a}$ & $5.3 \mathrm{a}$ & $5.4 \mathrm{a}$ & $5.7 \mathrm{a}$ \\
Foreign odour & $0.9 \mathrm{~b}$ & $1.1 \mathrm{~b}$ & $2.2 \mathrm{a}$ & $2.2 \mathrm{a}$ & $0.8 \mathrm{~b}$ \\
Foreign flavour & $1.7 \mathrm{~b}$ & $1.7 \mathrm{~b}$ & $2.8 \mathrm{a}$ & $2.6 \mathrm{a}$ & $0.8 \mathrm{~b}$ \\
\hline
\end{tabular}

Means within a row that do not share the same letter are significantly different at the $5 \%$ level.

Pasture species also influenced ultimate $\mathrm{pH}$., sheep meat odour, foreign odours and flavours, but did not affect sheep meat flavour as assessed by a scientific panel.

\section{ACKNOWLEDGEMENTS}

The authors would like to thank the Meat Research Development Council and the Foundation for Research,
Science and Technology for funding, Mr Trevor Knight and Mrs J. Deaker for assistance, and Dr A. Bray for comments on the manuscript.

\section{REFERENCES}

Cramer, D.A.; Barton, R.A.; Shorland, F.B.; Czochanska, Z. 1967. A comparison of the effects of white clover (Trifolium repens) and of perennial ryegrass (Lolium perenne) on fat composition and flavour of lamb. Journal of agricultural science, Cambridge 69: 367373.

Cummings, T.L. 1989. New cooking methods for meat minces prepared for analytical taste panels. Meat Indutry Research Institute of New Zealand RM 189.

Czochanska, Z.; Shorland, F.B.; Barton, R.A.; Rae, A.L. 1970. A note on the effect of the length of the resting period before slaughter on the intensity of flavour and odour of lamb. New Zealand Journal of Agricultural Research 13: 662-663.

Deaker, J.M.; Young, M.; Fraser, T.J.; Rowarth, J.S. 1994. Carcass composition of lambs grazing plantain (Plantago lanceolata), chicory (Cichorium intybus), white clover (Trifolium repens) or ryegrass (Lolium perenne). Proceedings of the New Zealand Society of Animal Production 54: 197-200

Dorfler, H.; Roselt, G. 1989. The dictionary of healing plants. London, New York and Sydney, Blandford Press, 328pp.

Fraser, T.J.; Rowarth, J.S. 1996. Legumes, herbs or grass for animal performance? Proceedings of the New Zealand Grassland Association 58: this issue.

Koong, L.J.; Neinaber, A.J.; Mersmann, H.J. 1983. Effects of plane of nutrition and organ size and fasting heat production in geetically obese and lean pigs. Journal of nutrition 113: 1626-1631.

Purchas, R.W.; Keogh, R.G. 1984. Fatness of lambs grazed on 'Grasslands Maku' lotus and 'Grasslands Huia' white clover. Proceedings of the New Zealand Society of Animal Production 44: 219-222.

Purchas, R.W.; Johnson, C.B.; Birch, E.J.; Winger, R.J.; Hagyard, C.J.; Keogh, R.G. 1986. Flavour studies with beef and lamb. Massey University, unpubl.

Shorland, F.B.; Czochanska, Z.; Moy, M.; Barton, R.A.; Rae, A.L. 1970. Influence of pasture species on the flavour, odour and keeping quality of lamb and mutton. Journal of the science offood and agriculture 21: $1-4$

Suzuki, J. 1985. Influence of finishing diets on objective and subjective flavour of lamb. Unpubl. PhD thesis, University of Missouri, Columbia.

Terrill, T.H; Douglas, G.B.; Foote, A.G.; Purchas, R.W.; Wilson, G.F.; Barry, T.N. 1992a. Effect of condensed 
tannins upon body growth, wool growth and rumen metabolism in sheep grazing sulla (Hedysarum coronarium) and perennial pasture. Journal of agricultural science, Cambridge 119: 265-273.

Terrill, T.H.; Rowan, A.M.; Douglas, G.B.; Barry, T.N. 1992b. Determination of extractable and bound condensed tannin concentrations in forage plants, protein concentrate meals and cereal grains. Journal of the science of food and agriculture 58: 321-329.

Young, O.A.; Reid, D.H.; Scales, G.H. 1993. Effect of breed and ultimate $\mathrm{pH}$ on odour and flavour of sheep meat. New Zealand journal of agricultural research 36: 363-370. 